\title{
Analysis How to Practice The Good Corporate Governance Principles of The Health Personnel In Puskesmas Cikulur, Lebak Banten Province
}

\author{
Putri Permatasari* \\ Universitas Pembangunan Nasional Veteran Jakarta, Indonesia \\ *ppermatasari8@gmail.com
}

\begin{abstract}
The application of Good Corporate Governance is believed to provide a strategic contribution in improving the performance of health personnel. The principles of Good Corporate Governance include transparency, accountability, responsibility, independence and fairness which are used as variables in this study. This study aimed to analyze the relation between principles of Good Corporate Governance and the performance of nonmedical personnel at the Cikulur Primary Health Care. This study used a cross sectional design with 81 research samples consisting of health personnel. The research instrument used was a questionnaire. Data were analyzed with chi square test to see the relationship between independent and dependent variables. Based on the results of the study, principles of transparency, accountability, and independence in Good Corporate Governance significantly related to the performance of health personnel. While other variables such as the principle of accountability and independence are not related to the performance of health personnel. In this research, suggested that in improving performance, all parties in the hospital need to realize the importance of applying the principles of Good Corporate Governance, especially the principles of transparency, accountability and independence.
\end{abstract}

Keywords: Performance, Good Corporate Governance, Health Personnel 


\section{STRADA Jurnal Ilmiah Kesehatan}

DOI: $10.30994 /$ sjik.v9i2.476

ISSN: 2252-3847 (print); 2614-350X (online)

Vol.9 No.2 November 2020 Page.1380-1389

\section{BACKGROUND}

The quality of puskesmas services comes from the effect of a synergistic collaboration between medical and non-medical staff which will result in maximum service quality. Because if the hospital only has good performing medical staff, but nonmedical \& support staff have poor performance, this can lead to problems in the hospital such as long queues at the patient registration and in the pharmacy unit, as well as other job imbalances that can harm patients. and creating poor quality health services. Therefore, in carrying out its duties, in addition to health workers, hospitals must also have good health workers (Azrul, 2010).

Efficient and effective management is a method used by hospital superiors in achieving predetermined goals and obtaining satisfactory work results. In this context the application of the principles of Good Corporate Governance can play a role in assessing the good and bad performance of human resources (Surya \& Yustaivandana, 2008) Good Corporate Governance is good corporate governance to deal with policy issues at all levels based on the principles of transparency, accountability, responsibility, participation, as well as a high level of sensitivity to the Law.

Factors that can lead to poor performance are weak implementation of Good Corporate Governance such as bribery, collusion, corruption \& nepotism (KKN). It is believed that the implementation of good Good Corporate Governance can make a strategic contribution in improving performance, creating a healthy business climate, increasing competitiveness, and being very effective in avoiding irregularities and preventing corruption and bribery. This will lead to efforts to achieve balanced profit and sustainability (Oktavianto, Yaningwati, \& A, 2014).

The implementation of Good Corporate Governance aims to create transparent information dissemination, create a sense of leadership responsibility, create equal treatment and accept their rights and obligations as hospital employees. The main objective of implementing the principles of Good Corporate Governance is to optimize the performance of employees, which in essence will improve organizational performance, so the interests of management and employees must receive a balanced and fair treatment according to their respective positions (Marniati, 2010). In the research (Marniati, 2010) states the principles of openness, accountability, fairness and participation have a significant effect on employee performance.

Employees are required to have high abilities and are continuously motivated. Based on the results of interviews during the preliminary study with the Head of HR that the implementation of Good Corporate Governance has been implemented. As in the principle of transparency regarding the recruitment system, Puskesmas usually open job vacancies in a transparent manner. Meanwhile, in the application of the principle of justice, everyone has the same rights and the results are fair regarding the recruitment system. In applying the principle of accountability, workers who have good professionalism and knowledge and accordingly give priority to the selection of the recruitment system. Likewise in applying the principle of participation related to logistics procurement, the Cikulur Health Center routinely invites colleagues to attend meetings and negotiations.

Regarding the reward and punishment system at Cikulur Health Center, it has been implemented but has not run optimally because sometimes the reward is not given in material form. A successful reward system will increase the enthusiasm of employees 


\section{STRADA Jurnal Ilmiah Kesehatan}

DOI: $10.30994 /$ sjik.v9i2.476

ISSN: 2252-3847 (print); 2614-350X (online)

Vol.9 No.2 November 2020 Page.1380-1389

within the company to work well. Because according to Maslow's theory, appreciation and self-actualization are the highest human needs. Giving rewards appropriately will motivate staff to work harder. A synergistic work environment of human resources is expected to create the best results in providing services to patients in a fair and equitable manner (Surya \& Yustaivandana, 2008).

In addition, the employee turnover rate is important in the company. Turnover is the level of employees leaving the company. The high rate of turnover can be caused by various factors such as motivation to get a better job (Harnoto, 2002).

According to (Lockhead \& Alex, 2004) in (Sumarni, 2011) when a company has employees who leave the company, this will cause the company to lose performance, knowledge and business reputation. This will be of concern to management because it has an impact on the efficiency, competitiveness, service quality and products of the company. The length of work of Cikulur Health Center employees who make turnover varies, dominated by employees with short working periods.

According to the results of research conducted by (Prawitasari, 2016) length of work is one of the factors of turnover. Usually employees who have a long working period will feel heavy hearted to leave the company. The turnover rate plays an important role in the performance of the puskesmas. High turnover rates can have an impact such as Puskesmas incurring extra costs in recruiting new staff and in implementing staff training, as well as decreasing profits due to reduced profitability (new workers have an average productivity of only $25-50 \%$ at the start of 3 months) (Sumarni, 2011).

Based on the problems mentioned above, the researchers conducted research on the relationship between the application of the principles of Good Corporate Governance (transparency, accountability, responsibility, independence \& justice) with the performance of health workers at Cikulur Health Center.

\section{METHODS}

This research is a quantitative analytic study with cross sectional research design. This study used a cross sectional research design because this study aimed to determine the relationship between the dependent variable (Health Worker Performance) and the independent (Good Corporate Governance principles) at one time without further followup.

The population in this study were 81 health workers working at the Cikulur Health Center. The sample calculation in this study used a hypothesis test formula with different proportions in the WHO Sample Size application, namely total sampling. At the time of the research, the number of samples obtained in this study were 81 respondents.

Primary data of the study were obtained using interview techniques and distributing questionnaires to health workers at the Cikulur Health Center related to the application of the principles of Good Corporate Governance and the performance of health workers. Secondary data obtained from literature sources in the form of theoretical data that support this research and data obtained from Cikulur Health Center. Data analysis used the chisquare test with a value of $\alpha=0.05$ to see the relationship between the principles of Good Corporate Governance and the performance of health workers. 


\section{STRADA Jurnal Ilmiah Kesehatan}

DOI: $10.30994 /$ sjik.v9i2.476

ISSN: 2252-3847 (print); 2614-350X (online)

Vol.9 No.2 November 2020 Page.1380-1389

\section{RESULTS}

Health Worker Performance

Table 1 Distribution of Frequency of Health Worker Performance

\begin{tabular}{llll}
\hline No. & Performance & Total & $\mathbf{( \% )}$ \\
\hline 1. & Not Good & 16 & 19,75 \\
2. & Good & 65 & 80,24 \\
\hline & Total & 81 & 100 \\
\hline
\end{tabular}

Table 1 shows that the respondents who were health workers at the Cikulur Health Center with poor performance totaled 16 respondents $(19.75 \%)$.

\section{Good Corporate Governance Principles}

Table 2 Frequency Distribution of Good Corporate Governance Principles

\begin{tabular}{lll}
\hline Variabel & Total & $(\mathbf{\%})$ \\
\hline Transparency & & \\
It is not in accordance with & 22 & 27,16 \\
Corresponding & 59 & 72,84 \\
Accountability & & \\
It is not in accordance with & 25 & 30,86 \\
Corresponding & 56 & 69,14 \\
Accountability & & \\
It is not in accordance with & 34 & 41,98 \\
Corresponding & 47 & 58,02 \\
Independence & & \\
It is not in accordance with & 28 & 34,57 \\
Corresponding & 53 & 65,43 \\
Justice & & \\
It is not in accordance with & 35 & 43,21 \\
Corresponding & 46 & 56,79 \\
\hline Total & $\mathbf{8 1}$ & $\mathbf{1 0 0}$ \\
\hline
\end{tabular}

Table 2 shows that as many as 22 respondents (27.16\%) chose the application of the principle of justice at Cikulur Health Center to be inappropriate. Respondents who chose the application of the principle of accountability at the Cikulur Community Health Center were 25 respondents $(30.86 \%)$. In applying the transparency principle at Cikulur Health Center, 34 respondents $(41.98 \%)$ chose that the application was not appropriate. In applying the principle of independence at Cikulur Health Center, 28 respondents $(34.57 \%)$ chose that the application was not appropriate. Respondents who chose the application of the principle of accountability at the Cikulur Health Center that were not appropriate were 35 respondents $(43.21 \%)$. 


\section{STRADA Jurnal Ilmiah Kesehatan}

DOI: $10.30994 /$ sjik.v9i2.476

ISSN: 2252-3847 (print); 2614-350X (online)

Vol.9 No.2 November 2020 Page.1380-1389

Relationship between Good Corporate Governance Principles and Health Worker Performance

Table 4 The Relationship between Good Corporate Governance Principles and Health Worker Performance

\begin{tabular}{|c|c|c|c|c|c|c|c|c|c|}
\hline \multirow{3}{*}{ Variable } & \multicolumn{4}{|c|}{ Performance } & \multirow{2}{*}{\multicolumn{2}{|c|}{ Total }} & \multirow{3}{*}{ P-value } & \multirow{3}{*}{ OR } & \multirow{3}{*}{$(95 \% \mathrm{CI})$} \\
\hline & \multicolumn{2}{|c|}{ Not Good } & \multicolumn{2}{|c|}{ Good } & & & & & \\
\hline & $\mathbf{N}$ & $\%$ & $\mathbf{N}$ & $\%$ & $\mathbf{N}$ & $\%$ & & & \\
\hline \multicolumn{10}{|l|}{ Transparency } \\
\hline $\begin{array}{l}\text { It is not in } \\
\text { accordance with }\end{array}$ & 7 & 31,81 & 15 & 68,19 & 22 & 100 & 0,038 & 2,505 & $1,128-5,564$ \\
\hline Corresponding & 11 & 18,64 & 48 & 81,36 & 59 & 100 & & & \\
\hline \multicolumn{10}{|l|}{ Accountability } \\
\hline $\begin{array}{l}\text { It is not in } \\
\text { accordance with }\end{array}$ & 10 & 40 & 15 & 60 & 25 & 100 & 0,034 & 2,519 & $1,142-5,555$ \\
\hline Corresponding & 18 & 32,14 & 38 & 67,86 & 56 & 100 & & & \\
\hline \multicolumn{10}{|l|}{ Accountability } \\
\hline $\begin{array}{l}\text { It is not in } \\
\text { accordance with }\end{array}$ & 13 & 30,95 & 39 & 69,05 & 42 & 100 & 0,944 & 0,879 & $0,371-2,085$ \\
\hline Corresponding & 15 & 51,72 & 14 & 48,28 & 29 & 100 & & & \\
\hline \multicolumn{10}{|l|}{ Independence } \\
\hline $\begin{array}{l}\text { It is not in } \\
\text { accordance with }\end{array}$ & 8 & 28,57 & 20 & 71,43 & 28 & 100 & 0,029 & 2,655 & $1,178-5,979$ \\
\hline Corresponding & 17 & 32,08 & 36 & 67,92 & 53 & 100 & & & \\
\hline \multicolumn{10}{|l|}{ Justice } \\
\hline $\begin{array}{l}\text { It is not in } \\
\text { accordance with }\end{array}$ & 11 & 18,33 & 49 & 81,67 & 60 & 100 & 0,302 & 1,623 & $0,747-3,525$ \\
\hline Corresponding & 10 & 47,62 & 11 & 52,38 & 21 & 100 & & & \\
\hline
\end{tabular}

The results of statistical analysis of the relationship between the principle of transparency and the performance of health workers show that the relationship between the application of the principle of transparency that is not appropriate at Cikulur Health Center can affect the performance of health workers, namely producing health workers who have poor performance as many as 7 respondents $(31.81 \%)$ good performance as many as 15 respondents $(68.19 \%)$. The results of statistical tests show that the value of $p<0.05$ ( $p=$ 0.038 ), this means that there is a significant relationship between the principle of transparency in Good Corporate Governance and the performance of health workers at Cikulur Health Center. From the analysis results also obtained OR $=2.505$, meaning that the application of the principle of transparency that is not suitable has a 2.5 times chance of having health workers with poor performance compared to the application of the appropriate principles.

The results of statistical analysis of the relationship between the principle of accountability and the performance of health workers show that out of 10 respondents (40\%) who have poor performance is the result of inappropriate application of the accountability principle and 15 respondents $(60 \%)$ have a good performance. If seen from the $\mathrm{P}$ value obtained is 0.034 where the $\mathrm{P}$ value $<0.05$, which means that there is a significant relationship between the principle of accountability in Good Corporate Governance and the performance of health workers at Cikulur Health Center. From the results of the analysis, it 


\section{STRADA Jurnal Ilmiah Kesehatan}

DOI: $10.30994 /$ sjik.v9i2.476

ISSN: 2252-3847 (print); 2614-350X (online)

Vol.9 No.2 November 2020 Page.1380-1389

was also obtained that the OR value $=2.519$, meaning that the application of the principle of accountability that is not suitable has a 2.5 times chance of having health workers with poor performance compared to the application of the appropriate principles.

The results of statistical analysis of the relationship between the principle of responsibility and the performance of health workers found that the application of the principle of accountability in Cikulur Community Health Center resulted in 13 respondents $(30.95 \%)$ with poor performance and 39 respondents $(69,05 \%)$. The results of statistical tests obtained $\mathrm{p}$ value $=0.994$, it can be concluded that there is no significant relationship between the principle of accountability in Good Corporate Governance and the performance of health workers at Cikulur Health Center.

The results of the statistical analysis of the relationship between the principle of independence and the performance of health workers showed that out of 8 respondents (28.57\%) had a poor performance was the result of the inappropriate application of the principle of independence at Cikulur Health Center and 20 respondents $(71.43 \%)$ had a poor performance good. If seen from the $\mathrm{P}$ value obtained is 0.029 where the $\mathrm{P}$ value $<0.05$, which means that there is a significant relationship between the principles of independence in Good Corporate Governance and the performance of health workers at Cikulur Health Center. From the analysis results also obtained OR $=2.655$, meaning that inappropriate application of the transparency principle has a 2.6 times chance of having health workers with poor performance compared to the application of the appropriate principles.

The results of statistical analysis of the relationship between the principle of justice and the performance of health workers found that the application of the principle of justice that was not appropriate at Cikulur Health Center resulted in 11 respondents (18.33\%) with poor performance and 49 respondents $(81,67 \%)$. The results of statistical tests obtained $p$ value $=0.302$, it can be concluded that there is no significant relationship between the principle of fairness in Good Corporate Governance and the performance of health workers at Cikulur Health Center.

\section{DISCUSSION}

\section{Analysis of the Relationship between the Principles of Transparency and the Performance of Health Workers}

The statistical tests that have been conducted have resulted in a statement that there is a significant relationship between the principle of transparency in Good Corporate Governance and the performance of health workers at Cikulur Health Center. In an organization, the principle of transparency functions to guarantee freedom for each member to know or obtain information about the organization or implementation and objectives of the organization. According to BUMN, transparency implies openness in decision making and honesty in disclosing relevant information. Several applications of the principle of transparency include those related to employee wages, related to layoffs to ensure that employees do not feel unilaterally disadvantaged, and transparent in disseminating information made by superiors (BUMN, 2011).

\section{Analysis of the Relationship between the Principles of Accountability and the Performance of Health Workers}

The statistical test that has been conducted has resulted in a statement that there is a significant relationship between the principle of accountability in Good Corporate 


\section{STRADA Jurnal Ilmiah Kesehatan}

DOI: $10.30994 /$ sjik.v9i2.476

ISSN: 2252-3847 (print); 2614-350X (online)

Vol.9 No.2 November 2020 Page.1380-1389

Governance and the performance of health workers at Cikulur Health Center. Accountability is a clarity of function and implementation, so that management is responsive, effective and efficient (BUMN, 2011). Lack of accountability can lead to a potential conflict of interest, therefore it can result in low management integrity and poor business ethics (Sutedi, 2012).

Analysis of the Relationship between the Principles of Accountability and the Performance of Health Workers

The results of this study indicate that there is no significant relationship between the principle of responsibility for Good Corporate Governance and the performance of health workers at Cikulur Health Center. Accountability is a method of business conformity with laws and laws, and social responsibility for the protection of the environment \& surrounding communities (Nyoto, 2016). In relation to the principle of responsibility, companies must comply with laws and regulations and carry out responsibility for the community and the environment so that business continuity can be maintained in the long term and gain recognition as a good corporate citizen (National Committee on Governace Policy, 2011).

\section{Analysis of the Relationship between the Principles of Independence and the Performance of Health Workers}

The results of this study indicate that there is a significant relationship between the principles of independence in Good Corporate Governance and the performance of health workers at Cikulur Health Center. In relation to the principle of independence, the hospital must be managed independently so that each hospital organ and its staff cannot dominate each other and cannot be intervened by any party (National Committee for Government Policy, 2011). Independence means the implementation of professional management in a company without conflict of interest and control or coercion from any entity that is not in accordance with laws and regulations and good business standards (PERMENDAGRI No $61,2007)$.

\section{Analysis of the Relationship between the Principles of Justice and the Performance of Health Workers}

The statistical test that has been conducted has resulted in a statement that there is no significant relationship between the principle of fairness in Good Corporate Governance and the performance of health workers at Cikulur Health Center. Justice is an equal attitude with respect to the enforcement of the rights of the parties based on agreements and applicable laws and regulations. An example of the application of justice is to provide all workers with promotions in career development according to their competencies, regardless of ethnicity, race, religion, and physicality (Lamadjido et al., 2013). Justice requires aspects of equal treatment and equal opportunities. Organizations must always consider the interests of stakeholders when carrying out their operations based on the concept of equality (National Committee for Governance Policy, 2011). Justice is an equal attitude regarding the fulfillment of the rights and obligations of stakeholders arising from 


\section{STRADA Jurnal Ilmiah Kesehatan}

DOI: $10.30994 /$ sjik.v9i2.476

ISSN: 2252-3847 (print); 2614-350X (online)

Vol.9 No.2 November 2020 Page.1380-1389

a healthy business behavior agreement, laws and regulations as well as from ethical values

(OJK, 2014)

\section{CONCLUSION}

The performance of health personnel at the Cikulur Health Center was good, as seen from 95 respondents $(72.5 \%)$ who had a good performance assessment, while 36 respondents $(27.5 \%)$ had a poor performance assessment.

There is a relationship between the principle of transparency in Good Corporate Governance and the performance of health workers at Cikulur Health Center.

There is a relationship between the principle of accountability in Good Corporate Governance and the performance of health workers at Cikulur Health Center.

There is no relationship between the principle of accountability in Good Corporate Governance and the performance of health workers at Cikulur Health Center.

There is a relationship between the principle of independence in Good Corporate Governance and the performance of health workers at Cikulur Health Center.

There is no relationship between the principle of fairness in Good Corporate Governance and the performance of health workers at Cikulur Health Center.

\section{REFERENCES}

Azrul, Azwar. 2010. Pengantar Administrasi Kesehatan, Edisi Ketiga. Jakarta: Binarupa Aksara Publisher.

BUMN. 2011. "PER-01/MBU/ 2011.” http://jdih.bumn.go.id/baca/PER01/MBU/2011.pdf.

Effendi, Muh. Arief. 2009. The Power of Good Corporate Governance Teori Dan Implementasi. Jakarta: Salemba Empat.

Fahmi, Irham. 2012. Analisis Kinerja Keuangan. Bandung: Alfabeta.

Gibson, James L., John M. Ivancevich, and James H. Donnelly. 2011. Organisasi : Perilaku, Struktur, Proses. edited by N. Adiarni. Jakarta: Binarupa Aksara.

Handoko, T. Hani. 2013. Manajemen Edisi 2. Yogyakarta: BPFE.

Harlan, Johan and Rita Sutjiaji Johan. 2018. Metodologi Penelitian Kesehatan. Vol. 53. Depok: Universitas Gunadarma.

Harnoto. 2002. Manajemen Sumber Daya Manusia. 2nd ed. Jakarta: PT. Prenhallindo.

Hasan, Muhammad, Dumilah Ayuningtyas, and Misnaniarti. 2016. "Good Corporate Governance Implementation and Performance of Civil Servant." Kesmas: National Public Health Journal 11(1):20-25.

Hati, Shinta Wahyu and Awik Arumsasmy. 2017. "Analisis Penerapan Prinsip Good Governance Terhadap Kinerja Pegawai Di Politeknik Negeri Batam.” EJournal Ilmu Pemerintahan 4(1):102-14.

Lamadjido, Reny Arniwaty, Darmawansyah, and Noer Bahry Noor. 2013. "Penerapan Prinsip Good Coorporate Governance Terhadap Kepuasan Pasien Di RSU Anutapura Palu." Jurnal AKK 2(2):1-9.

Lemeshow, Stanley, David W. Hosmer, Janelle Klar, and Stephen K. Lwanga. 1990. Adequacy of Sample Size in Health Studies. Vol. 47. Jenewa: John Wiley \& Sons Ltd.

Lockhead, Clearence and Stephens Alex. 2004. Employee Retention, Labour Turnover and Knowledge Transfer: Case Studies from Canadian Plastic Sector. Canada. 


\section{STRADA Jurnal Ilmiah Kesehatan}

DOI: $10.30994 /$ sjik.v9i2.476

ISSN: 2252-3847 (print); 2614-350X (online)

Vol.9 No.2 November 2020 Page.1380-1389

Mahadewi, Ida Ayu Arina and I. G. A. M. Asri Dwija Putri. 2019. "Pengaruh Penerapan Prinsip-Prinsip Good Governance Terhadap Kinerja Pada Rumah Sakit Di Kota Denpasasar." E-Jurnal Akuntansi Universitas Udayana 27:568-93.

Mahsun, Muhamad. 2012. Pengukuran Kinerja Sektor Publik. Yogyakarta: BPFE.

Mangkunegara, Anwar Prabu. 2011. Manajemen Sumber Daya Perusahaan. Bandung: PT Remaja Rosdakarya.

Masram and Mu'ah. 2015. Manajemen Sumber Daya Manusia. 1st ed. Sidoarjo: Zifatama.

Masturoh, Imas and Nauri Anggita Temesvari. 2018. Metodologi Penelitian Kesehatan. 1st ed. Jakarta: BPPSDM Kesehatan.

Moeheriono. 2010. Pengukuran Kinerja Berbasis Kompetensi. Surabaya: Ghalia Indonesia.

Muninjaya. 2012. Manajemen Kesehatan. 3rd ed. Jakarta: EGC.

Notoatmodjo, Soekidjo. 2010. Metodologi Penelitian Kesehatan. Jakarta: Rineka Cipta.

Nyoto, Christian Chandra. 2016. "Implementasi Prinsip-Prinsip Good Corporate Governance Pada Rumah Sakit." AGORA 4(2):869-74.

OJK. 2014. "Peraturan Otoritas Jasa Keuangan Nomor 2/POJK.05/2014 Tentang Tata Kelola Perusahaan Yang Baik Bagi Perusahaan Perasuransian."

Oktavianto, Yogy, Fransisca Yaningwati, and Zahroh Z. A. 2014. "Penerapan Good Corporate Governnace Untuk Meningkatkan Kinerja Perusahaan (Studi Pada PT. HM Sampoerna,Tbk Yang Listing Di BEI Periode 2010-2012)." Jurnal Administrasi Bisnis S1 Universitas Brawijaya 9(2).

PERMENDAGRI No 61. 2007. "Permendagri No. 61 Tahun 2007." 3.

Prabowo, Muhammad Shidqon. 2018. Dasar-Dasar Good Corporate Governance. Yogyakarta: UII Press.

Prawitasari, Andriyani. 2016. "Faktor-Faktor Yang Mempengaruhi Turnover Intention Karyawan Pada PT. Mandiri Tunas Finance Bengkulu.” Ekombis Review 4(2):17786.

Pribadi, Firman, Erwin Santosa, and Bobet Evih Hedi Ihnuna Rusep. 2012. "Good Corporate Governance in Hospitals A and B." 1-24.

Putra, Hendra G. 2014. "Pengaruh Akuntabilitas, Transparansi, Dan Partisipasi Publik Terhadap Kinerja Organisasi Layanan Publik." Jurnal Akuntansi 2(3):23.

Putriany, Dela. 2018. "Pelaksanaan Tata Kelola Pelayanan Kesehatan." Jurnal Demokrasi \& Otonomi Daerah 16(3):81-164.

Sedarmayanti. 2011. Manajemen Sumber Daya Manusia. 5th ed. Bandung: PT Refika Aditama.

Stanislaus, Uyanto. 2006. Pedoman Analisis Data Dengan SPSS. Yogyakarta: Graha Ilmu.

Sugiyono. 2014. Metode Penelitian Pendidikan Pendekatan Kuantitatif, Kualitatif, Dan $R \& D$. Bandung: Alfabeta.

Sulistiyani, Ambar Teguh. 2011. Memahami Good Governance: Dalam Perspekstif Simber Daya Manusia. Yogyakarta: Gava Media.

Sumarni, Murti. 2011. "Pengaruh Employee Retention Terhadap Turnover Intention Dan Kinerja Karyawan." Akmenika UPY 8:20-47.

Surya and Yustaivandana. 2008. "Penerapan Good Corparate Governance, Mengesampingkan Hak-Hak Istimewa Demi Kelangsungan Usaha, Diterbitkan Oleh Kerja Sama Dengan Lembaga Kajian Pasar Modal Dan Keuangan (LKPMK).” Fakultas Hukum Universitas Indonesia.

Sutedi. 2012. Good Corporate Governance. Jakarta: Sinar Grafika.

Sutrisno, Edi. 2011. Manajemen Sumber Daya Manusia. Jakarta: Kencana 


\section{STRADA Jurnal Ilmiah Kesehatan}

DOI: $10.30994 /$ sjik.v9i2.476

ISSN: 2252-3847 (print); 2614-350X (online)

Vol.9 No.2 November 2020 Page.1380-1389

Suwati, Yuli. 2013. "Pengaruh Kompensasi Dan Motivasi Kerja Terhadap Kinerja Karyawan Pada PT Tunas Hijau Samarinda." Jurnal Ilmu Administrasi Bisnis 1(1).

UU No. 36. 2009. Undang-Undang Republik Indonesia Nomor 36 Tahun 2009 Tentang Kesehatan. Jakarta: Indonesia.

UU No. 44. 2009. "Undang-Undang Republik Indonesia Nomor 36 Tahun 2009 Tentang Kesehatan."

Wibowo, Edi. 2010. "Implementasi Good Corporate Governance Di Indonesia." Jurnal Ekonomi Dan Kewirausahaan 10(2):129-38.

Wirnipin, Komang Sri, I. Made Pradana Adiputra, and Gede Adi Yuniarta. 2015. "Pengaruh Komitmen Organisasi, Budaya Organisasi, Dan Akuntabilitas Publik Terhadap Kinerja Organisasi Publik Pada Rumah Sakit Umum Daerah Kabupaten Buleleng." E-Journal S1 Ak Universitas Pendidikan Ganesha 3(1):1-12. 